\title{
Performance Audits Focused on the Principle of Effectiveness: An Overview of Public Audit Agencies
}

\author{
Luiz G M Mury \\ Correspondence: Luiz G M Mury, Post-doctorate in Economics at Federal University of RS, Porto Alegre, Brazil; \\ Public auditor at RS State Court of Accounts, Brazil.
}

\author{
Received: July 1, 2018 \\ Accepted: July 24, 2018 \\ Available online: July 27, 2018 \\ doi:10.11114/afa.v4i2.3488 \\ URL: https://doi.org/10.11114/afa.v4i2.3488
}

\begin{abstract}
According to international standards, performance audit is an independent and objective process for reviewing the economy, efficiency and effectiveness of a government's program, organization, and/or activity in order to evaluate public management's performance. The relevance of the matter prompted the present study, which aims to inquire if, when conducting performance audits, Supreme Audit Institutions analyze a procedure's effectiveness, that is to say, the impact that determined government spending had on the program's target population. In order to do so, a questionnaire was applied to auditors of Public Audit Institutions from several countries. As a preliminary result, our research concluded that the majority of auditors conduct economy, efficiency and efficacy analyses, but rarely assess the effectiveness of government spending.
\end{abstract}

Keywords: performance audit, court of auditors, effectiveness

\section{Introduction}

Until early 1970's, the majority of Supreme Audit Institutions [SAI] had as their primary goal a formal nature of control focused on the validation of evenness of government spending execution, the legal compliance of administrative acts, and the consistency of financial demonstratives. When States started to face financial difficulties, SAIs work routines began to gradually change. One can identify four socioeconomic factors that triggered such changes. First, governments accumulated many activities after World War II and were, thus, overwhelmed. Also, taxpayers refused to pay more taxes for not realizing the connection between the improvement of public services and the need for increasing government resources, what led to a Fiscal Crisis. Second, the harmful effects the oil crises brought upon world's economy in 1973. Third, the Welfare State Crisis, with neoliberal governments now considering privileges what interest groups perceived as achievements. Fourth, the globalization phenomenon, responsible for diminishing governmental power to control financial and business flow and to dictate macroeconomic policies (Mury, 2018 as cited in Abrucio, 1997).

The financial crises generated a demand for more efficiency, economy, and transparency in government spending. Along with such appeals, several countries also started to reform their public services according to economic theories and principles developed for the private sector (Vabo, 2009). The goal of this wave of reforms - referred to in the literature as the New Public Management [NPM] was to make public services more citizen-oriented and to improve their efficiency by using private sector management models.

Hood (1991) was the first to use the term NPM in his paper "A Public Management for All Seasons?" There he presented the fundamental principles of this approach. Amidst them one can point the following as essential: (i) Focus on private sector management style for public management practices; (ii) Performance assessments for the public sector; (iii) Emphasis on more discipline and parsimony when using public resources.

The first NPM practices took place in the United Kingdom under the leadership of Margaret Thatcher. As Prime Minister, Thatcher carried out changes in public management policy in issues such as organizational methods, labor relations, expenditure planning, financial management, audit, evaluation, and acquisitions.

The NPM advanced throughout the world promising to tackle two main bureaucratic burdens: the excess of procedures and the low bureaucrats' accountability when facing society and the political system (Sano, 2003). Its proposal was to make public administration more adjustable and to increase accountability through a new consumer-client focused service provision. In order to do so, it was important to change the public sector's methodology and emphasis through a better financial control, efficiency enhancement, the setting of objectives, and power delegation. But, in addition to that, 
it was also essential to monitor the results.

Financial and conformity reviews were no longer sufficient for governmental audits to assess this new model of public management, as it was now also necessary to examine government spending performance regarding economy, efficiency, and efficacy (Araujo, 2008), a process that became known as performance audit. Pollitt et al. (2008) ${ }^{1}$ endorsed this stance by affirming that performance audit emerged as a distinct form of assessing government spending as Western European, North American, and Australasian governments embarked on their extensive public management reform programs. Performance audit has become more significant in several countries since then. It even constitutes the main activity of several SAIs (Pollitt et al., p. 28) because of the substantial transference of productive activities to the private sector (either a complete transference or through public-private partnerships), with the State acting basically as an economic regulator. According to UK National Audit Office [NAO] (1997, as cited in Pollitt et al., 2008), two-thirds of governmental activities are now executed by (regulatory) agencies. Thus, the involvement of the private sector on State-funded programs has increased, causing the execution and the results to be more important than the process.

However, it is more difficult to measure the production (or output) of public entities in monetary terms as basic notions of profit and investment return do not apply. Thus, it became necessary to conduct more substantial examinations that could also assess the results obtained, i.e., the activity's impact on its target population.

Both administrators and citizens, in general, are concerned with whether financial accounts are correctly accounted for and without misappropriations. Yet, they are even more interested in knowing if government spending has been effective if it proceeded in an economic manner, and if public policies had a positive impact on people's lives. Providing an answer to such questions is part of performance audit's appeal.

\subsection{Hypothesis}

Given the context presented above, the hypothesis to be examined in this article is that SAIs, although they have legal attribution, rarely evaluate the effectiveness of public expenditure with regards to the impact on the population.

In order to exam the aforementioned hypothesis, we organized the remainder of this paper into three sections and a conclusion segment. Section two starts with a brief literature review on the historical evolution of performance audit, following a comparison between definitions of performance audit according to the International Organization of Supreme Audit Institutions [INTOSAI ${ }^{2}$ ] and the norms applied by some of the main SAIs. It ends with the presentation of the methods used in the elaboration of performance audits. Section three, on its turn, presents the fieldwork this research is built on and proceeds with the analyses of the collected data.

\section{Performance Audit: Evolution and Current Context}

As stated by Araújo (2008), the first official record of economy and efficiency evaluation in public management dates back to 1971, when the concept of "Comprehensive Audit" was presented at the INTOSAI Congress, in Canada. According to this new concept of auditing, the accounting responsibility examination that was already in play was not enough. It was necessary to include administrative and programmatic responsibility, which entailed evaluating economic and efficiency matters regarding the allocation of public resources. Furthermore, this new audit model, also known as integrated audit, could assess the scope of government objectives taking into account the costs and the objectives met.

In 1972, the American organization responsible for Audits, Evaluations and Investigations, the Government Accountability Office [GAO] published the first version of the book "Standards for Audit of Governmental Organizations, Programs, Activities, and Functions", which was last officially reviewed in 2011. Even on that first edition, the book pointed to the need for an extensive audit of institutions that manage public resources, in accordance to the concept of the comprehensive audit presented at the INTOSAI Congress in 1971 (GAO, 1972, p.2).

In 1976, these concepts were presented at GAO's $9^{\text {th }}$ Annual Seminar. In that occasion, the auditing of aspects such as economy, efficiency and effectiveness was named performance audit (Morse, 1976). The Lima Declaration of Guidelines on Auditing Precepts, formulated in 1977 at the IX International Congress of SAIs in Lima, Peru, globally consolidated these concepts:

Section 4. Legality audit, regularity audit and performance audit

1. The traditional task of Supreme Audit Institutions is to audit the legality and regularity of financial management and of accounting.

2. In addition to this type of audit, which retains its significance, there is another equally important type of audit--performance audit--which is oriented towards examining the performance, economy, efficiency and effectiveness of public administration. Performance audit covers not only specific financial operations but the full range of government activity including both organizational and administrative systems. 
3. The Supreme Audit Institution's audit objectives--legality, regularity, economy, efficiency, and effectiveness of financial management--basically are of equal importance. However, it is for each Supreme Audit Institution to determine its priorities on a case-by-case basis. (International Standards of Supreme Audit Institutions [ISSAI]) (highlighted by the author)

Ever since then, each country's SAI has regulated how performance audits are conducted. Due to the variety and complexity of the issues addressed, performance audits are more flexible than traditional ones when it comes to theme choice, auditing objects, work methods, and how to communicate its results (Brazilian Court of Audit [TCU], 2010).

Despite the existence of several international standards concerning performance audit, all of them address the same criteria: Economy, Efficiency, and Effectiveness of public activities.

ISSAI is INTOSAI's Professional Standards framework, which is structured on four levels. Level 1 (ISSAI 1) was presented at the INTOSAI Congress in 1977 and states the founding principles applicable to every auditing of the public sector regardless of its form or context. Level 2 (ISSAI 10-99) establishes the prerequisites for the satisfactory functioning and professional conduct of SAIs, e.g., independence, transparency, accountability, ethics and quality control. Level 3 (ISSAI 100-999), on the other hand, presents the fundamental auditing principles for each type of auditing: Financial, Performance and Compliance. Finally, level 4 (ISSAI 1000-4999) translates the founding principles into more specific and detailed auditing guidelines, which can be used to perform audits and also as the audit standards for countries that have not yet elaborated them. The ISSAI 300 standard, on page 2, designates Performance Audits as follows:

Performance auditing carried out by SAIs is an independent, objective and reliable examination of whether government undertakings, systems, operations, programs, activities or organizations are operating in accordance with the principles of economy, efficiency and/or effectiveness and whether there is room for improvement. (highlighted by the author)

The same standard ISSAI 300, on page 2, terms the principles of economy, efficiency, and effectiveness:

1) The principle of economy means minimizing the costs of resources. The resources used should be available in due time, in and of appropriate quantity and quality and at the best price.

2) The principle of efficiency means getting the most from the available resources. It is concerned with the relationship between resources employed and outputs delivered in terms of quantity, quality, and timing.

3) The principle of effectiveness concerns meeting the objectives set and achieving the intended results.

The Generally Accepted Government Auditing Standards (GAGAS), commonly referred to as the "Yellow Book", are produced in the United States by the GAO, and apply to both financial and performance audits of government agencies. According to GAO latest official edition from 2011, performance audits provide objective analysis to assist management and those charged with governance and oversight in using the information to improve program performance and operations, reduce costs, facilitate decision making by parties with responsibility to oversee or initiate corrective action, and contribute to public accountability.

Performance audit objectives vary widely and include assessments of program effectiveness, economy, and efficiency; internal control; compliance; and prospective analyses.

Audit objectives that focus on program effectiveness and results typically measure the extent to which a program is achieving its goals and objectives. Audit objectives that focus on economy and efficiency address the costs and resources used to achieve program results. (GAO-12-331G, p. 18)

The UK National Audit Office (NAO) also uses the three criteria ${ }^{4}$ to assess the value for money of government spending i.e. the optimal use of resources to achieve the intended outcomes. (Retrieved from https://www.nao.org.uk):

I) Economy: Minimizing the cost of resources used (inputs) - spending less;

II) Efficiency: The relationship between the output from goods or services and the resources to produce them spending well; and

III) Effectiveness: The relationship between the intended and actual results of public spending (outcomes) - spending wisely.

Australian Audit Courts, in its turn, apply the ASAE 3500 (Australian Auditing and Assurance Standards), which defines that the objective of performance engagements is to evaluate the performance of an activity with respect to economy, efficiency and/or effectiveness against the identified criteria. Performance engagements may include an examination of:

a) Economy, efficiency and/or effectiveness:

(i) In terms of management systems or an entity's management in order to contribute to improvements; 
(ii) Of the operations of an entity or an activity of an entity;

(iii) In the implementation of government policies or programs and the application of government grants;

(iv) In terms of financial prudence in the application of public resources; and

(v) Of administrative arrangements.

(b) Intended and unintended impacts of the implementation of government policies or programs and the extent to which community needs and stated objectives of an activity or entity have been met; (highlighted by the author) or

(c) Probity processes and identification of weaknesses.

The Finnish manual considers that the fundamental viewpoint in all performance audits is sound financial management or, in other words: economy, efficiency, and effectiveness. Sound financial management means that the responsible authority promotes the optimal use of resources to achieve intended outcomes with the lowest possible costs. This is based on the principle of economic rationality, according to which public resources should be used to achieve the greatest possible benefits. Each audit focuses attention on both: objectives and the costs of achieving them. The achievement of objectives cannot be evaluated without considering resulting costs. (National Audit Office of Finland, 2007).

For the Canadian Standard on Assurance Engagements [CSAE] Performance audits seek to determine whether government programs are being managed with due regard for economy, efficiency, and environmental impact and whether there are measures in place to determine their effectiveness. The principles of economy, efficiency and effectiveness are defined as follows (Retrieved from: http://www.oag-bvg.gc.ca/internet/methodology/performance-audit/manual/101.shtm):

I) The principle of economy means minimizing the costs of resources, with due regard to quality. The resources used have to be available in due time, in and of appropriate quantity and quality, and at the best price.

II) Efficiency is defined as the extent to which resources are used such that a greater level of output is produced with the same level of input or a lower level of input is used to produce the same level of output.

III) The principle of effectiveness concerns meeting the objectives set and achieving the intended results.

Finally, the European Court of Auditors understands performance audits as analyzing a public intervention in terms of a set of financial, organizational and human resources mobilized to achieve, in a given period of time, an objective or set of objectives, with the aim of solving or overcoming a problem or difficulty affecting targeted groups. The use of logic models can help the audit team to identify and set out the relationship between the socio-economic needs to be addressed by the intervention and its objectives, inputs, processes, outputs, and outcomes, which include results and impacts (longer-term effects of the intervention). The following diagram shows an example of their Program Logic Model:



Figure 1. Example of a Program Logic Model

Source: Performance Audit Manual (European Court of Auditors, p. 18) 
It is important to point out that one can measure the economy and efficiency of government spending without leaving the organization, while effectiveness requires an investigation of results/impacts with the target population. Its assessment is, therefore, of a more complex nature.

In order to perform audits that focus on economy and efficiency principles, one needs to conduct a process evaluation which, as stated by Gertler et al. (2016, p. 16), "focus on how a program is implemented and operates, assessing whether it conforms to its original design and documenting its development and operation". To audit the effectiveness principle, however, it is necessary to perform an impact evaluation, which is, according to Gertler et al. (2016, p. 328), "an evaluation that makes a causal link between a program or intervention and a set of outcomes. An impact evaluation answers the question: What is the impact (or causal effect) of a program on an outcome of interest". In other words, to ask what would have happened to the target-population if the government spending had not occurred? Barros (2012) supports this definition by stating that the impact of a program is defined as the contrast between two situations: a real one (the situation of the participants after the program is completed) and a hypothetical one (the situation they would be in had they not taken part in the program).

Process and impact evaluations also differ on the methodology applied. While the use of surveys, interviews, direct observation and descriptive statistics apply to process evaluation, according to Gertler et al. $(2016$, p. 8) every impact evaluation method addresses the cause-effect matter in some stance:

To be able to estimate the causal effect or impact of a program on outcomes, any impact evaluation method chosen must estimate the so-called counterfactual: that is, what would have been the outcome for program participants if they had not participated in the program. (highlighted by the author)

In practice, impact evaluation requires that the evaluation team find a comparison group (also known as control group) to estimate what happens to individuals who do not take part of the program and then make comparisons with the group that has participated in the program (also known as treatment group).

In their research originally published in 1999, Pollit et al. (2008) affirm that although SAIs displayed a predisposition to try new methodologies, they tend to apply consolidated and widely employed techniques. As a result, performance audit still had, as its core, a lot of the traditional audit. Furthermore, the researchers stated that they encountered some difficulty to analyze the methods applied in performance auditing. Partially because several reports use a variety of methods within the same study while others do not disclose much information on the methods eventually applied.

This matter was further analyzed by an INTOSAI workgroup which acknowledged that performance audits could be performed through a variety of methods and techniques, e.g.: focal groups, benchmarking, comparative studies between the situation before and after the program was implemented, quasi-experimental design, cost-benefit analysis, and cost-effectiveness analyses. Yet, according to Pollitt et al. (2008), most SAIs developed conservative organizational cultures in which its higher-ranked agents opt to perform their activities in the safest way possible. Hereof, a new work methodology could be considered strange, unreliable, or unfair to the audited agency ${ }^{6}$. Additionally, the SAIs themselves could have limited knowledge of the technique to be used what could lead to a wrongful conduction of such. The research also affirms that standpoints on good management practice were the standard most frequently and dominantly applied. In other words, in practice, many performance audits still assess compliance according to notions of good procedure instead of applying criteria for efficiency and effectiveness evaluation. Finally, the mentioned research concluded that analytical studies concerning efficiency and effectiveness were an exception, that is to say: many SAIs rely mainly upon interviews and document inspection instead of employing more sophisticated analytical techniques.

The variety of subjects, scope and approaches SAIs apply in their performance audit reports makes it impossible to frame their answers in one model. A similar struggle was presented by Pollitt et al. (2008) when describing how key-terms are not translated into equivalent terms in different languages - nor are their meanings entirely stable. Even within one national language, one can find significantly variable definitions of objectives, targets, effectiveness, efficiency, etc. Despite clearly stated in the standards, terms vary in meaning in different languages and even within the same language. In that respect, Pollitt et al (2008, p. 143) explain:

"it was clear to us that the equivalent term for 'effectiveness' in Sweden had been used over the years in a number of different ways within the RRV (National Audit Office). Besides, in several interviews conducted in several SAIs, it was clear that those interviewed used some criteria concepts in a very vague sense and also that they were variable."

Some SAIs, for instance, consider the exam of a program implementation as an effectiveness examination, while it should be seen as an efficacy evaluation. Difference between both concepts can be found in Gertler et al. (2016, p. 11):

"In the early days of impact evaluations of development programs, a large share of evidence was based on efficacy studies: studies carried out in a specific setting under closely controlled conditions to ensure fidelity between the evaluation design and program implementation. 
By contrast, effectiveness studies provide evidence from interventions that take place in normal circumstances, using regular implementation channels, and aim to produce findings that can be generalized to a large population" (highlighted by the author).

Aiming to identify weather SAIs are currently undertaking performance audits focusing on the principle of effectiveness through the impact evaluation of government spending, the present study was conducted with Court of Accounts auditors from different countries. The research methodology and analyses of the data collected are presented in the following section of this paper.

\section{Fieldwork Research - Methodology and Data Analyses}

Santos (2006) provides a classification of academic research according to its objectives, which can be explanatory, descriptive or exploratory. Concerning the sources to be investigated, the author separates them into bibliographical, derived from laboratory experiments, or fieldwork. He also affirms that data collection procedures required to gather the necessary information to construct logical thinking about a fact, phenomenon or process can involve experiments, case studies, bibliographical or documental research, action research, participant research, quantitative research, and qualitative research.

From these initial concepts it was defined that the methodology for the present research has an exploratory objective, the sources used being the bibliographical and the performance audit reports received, and whose procedure of data collection was a qualitative research carried out through a questionnaire sent via email to SAI auditors from various countries. Considering the academic status of the present research, the decision was to directly contact the auditors responsible for conducting performance audits in each institution. As a result, one must stress that the answers provided reflect the personal opinion of each agent and not the official position the institutions may have regarding this auditing modality. As of the writing of the present paper, auditors from eighteen SAIs had answered the survey and a few also provided performance audit reports they have written.

Even though the surveys were sent to public sector auditors from SAIs of over sixty countries, besides the European Union, the answers so far received come all from countries where, according to literature, the NPM was more strongly enforced when compared to countries with a strong Rechtsstaat or with rooted traditions in Administrative Law. The material gathered enables a number of studies of performance audits from different perspectives. However, in order to delimit the current study, the analysis here presented will be restricted to audits that examine effectiveness which, according to The World Bank's definition (Gertler et al., 2016), are those performed by an evaluation of impact. Through the analyses of the information received one can observe that the themes audited significantly vary. A contrast that can be partially explained by the fact that among those who answered the surveys there were federal, state and city auditors. A few SAIs opted to narrow their scope: education, health, and infrastructure. Others, instead, affirmed that:

"Our performance audits can focus on organizational structures and financing systems, the steering and management of activities, outputs and outcomes, the economy and effectiveness of activities or the impacts of activities."

According to international standards, performance audits must set a clear goal which must be connected to the principles of economy, efficiency, and effectiveness. When questioned about which principles were regularly examined almost all of the eighteen SAI auditors mentioned effectiveness. Assuming that impact evaluation is necessary for verifying the effectiveness of policies, programs, and government spending, our analyses proceeded to verify the methodologies employed on the performance audit reports that mentioned the principle of effectiveness.

The concept of methodology here used does not refer to the strategy applied to the undertaking of performance audits itself, but to data collection procedures which enable a quantitative analysis of the object that is being audited. The TCU elaborated a manual in 2010 in which it defines several data collection techniques such as surveys, interviews, direct observation and usage of existing data. The last is the object of the present research. According to the Manual:

Data analysis is usually an interactive procedure. That is to say that preliminary analyses are done during the planning stage and, as the audit progresses, the analyses are refined. A wide range of analysis techniques can be used when conducting a performance audit, including multivariate statistical analysis, data envelopment analysis, regression analysis. (TCU, 2010, p. 66, highlighted by the author).

One could also observe that most reports from the sample ${ }^{7}$ define effectiveness as the achievement of preset goals and not as the impacts verified. The following passages drawn from reports analyzed are representative of this matter:

Audit Report 1: "The effectiveness of the public administration can be assessed by comparing the planned and attained results and estimating whether the proportion between the resources used and the results achieved is optimal."

Audit Report 2: "Audit objectives that focus on program effectiveness and results typically measure the extent to which a program is achieving its goals and objectives." 
Audit Report 3: "Whether the use of resources and instruments in government administration are effective with a view to the goals set by $\mathrm{X}$ for the area."

Audit Report 4: "To enable the Ministry of X to assess the effectiveness of addiction programs, the Ministry should work to:

- establish acceptable targets for the indicators; and

- measure and report on variances between results achieved and established targets, and implement corrective action where needed."

Audit Report 5: But the effectiveness we only check the indicators of being effective so the focus is on achieving targets and Key Performance Indicators - KPIs, as well as checking if the plans are well designed and SMART ${ }^{8}$.

Nevertheless, not all SAIs understand effectiveness as the achievement of goals, as it can be seen in the following excerpts from some sample reports:

Audit Report 6: "The purpose of the audit was to assess the economic efficiency of entrepreneur education by examining the costs arising from the education and the process of purchasing the education services. The effectiveness and success of the education were assessed by analyzing the labor market situation of the participants after they had completed the courses.

\section{Entrepreneur education provided the participants with better employment prospects but generated little income for them}

The review covered the period between 2011 and 2015. The individuals selected for the assessment took part in entrepreneur education during 2014. The members of the control group did not take part in entrepreneur education or did not use other employment services during the same period. Based on the analysis results, entrepreneur education has improved the participants' employment prospects by an average of ten percentage points between 0.5 and 1.5 years after the education. Entrepreneur education has also led to a slight increase in the entrepreneur income of the participants."

Audit Report 7: "Immigrant students and the effectiveness of basic education. The main question asked in the audit was: How well does this overall objective apply to immigrant students? Firstly, the issue was approached by comparing the effectiveness of basic education among immigrant and native students. Effectiveness was measured using the PISA 2012 (Programme for International Student Assessment. See www.oecd.org/pisa/aboutpisa) test scores of 15-year-old students. Secondly, it was examined how immigrant students have been supported in the learning of $\mathrm{X}$ and their own mother tongue by the age of 15 . Thirdly, it was examined how immigrant students prepare for upper secondary level studies. As immigrant students are not a homogeneous group, consideration was also given to the effect of their country of origin and their age of arrival.

After statistically controlling for the grade of the student the performance gaps in mathematical, reading and scientific skills decrease by about 40 points (especially between first-generation immigrant and native students), which roughly corresponds to one school year's studies."

Audit Report 8: Impact of innovation support measures on the competitiveness of companies. Has the state supported the innovation of companies effectively?

The National Audit Office audited whether the support in the amount of ca X million euros, which was paid out during the period of 2007-2013 to promote the innovation and growth capacity of companies, has had any economic impact and thereby improved the competitiveness of companies. The audit assessed whether the measures have increased the companies' sales revenue, export sales revenue, added value and added value per employee, and whether it has improved the cooperation of companies with other companies and/or research and development organizations.

To find out the impact of support measures on the competitiveness of enterprises, NAO analyzed four non-performing economic indicators (sales revenue, export revenue, Added value and Added value per employee) of the recipients and of the enterprises that did not get the support. Changes in the economic indicators of beneficiaries were observed after 1 or 2 years from the ending of the project. 
Table 1. Results of the quantitative analysis of the audited measures

\begin{tabular}{c|c|c|c|c}
\hline Measure & $\begin{array}{c}\text { Sales } \\
\text { revenue }\end{array}$ & Export & Added value & $\begin{array}{c}\text { Added value per } \\
\text { employee }\end{array}$ \\
\hline Support of R\&D projects & No impact & No impact & No impact & No impact \\
\hline $\begin{array}{c}\text { Support of innovation units } \\
\text { Technology investment support to industrial } \\
\text { entrepreneurs }\end{array}$ & No impact & No impact & No impact & No impact \\
\hline $\begin{array}{c}\text { Programme for technology development } \\
\text { centres }\end{array}$ & No impact & There is impact & No impact & No impact \\
\hline $\begin{array}{c}\text { Cluster development programme } \\
\text { Programe for supporting investments in } \\
\text { science and technology parks }\end{array}$ & No impact & No impact & No impact & There is impact \\
\hline
\end{tabular}

Note: "There is impact" or "no impact" primarily characterize the existence or lack of a statistically significant difference between the mean value of the financial indicators of the companies that have and have not received support.

Looking at the six main measures aimed at supporting innovation, we can see that only three of them have had a positive impact on the companies' exports or added value. Based on these findings, NAO made several recommendations to improve the program.

The effectiveness audits of government spending above call attention to the need for developments that required a subsequent qualitative analysis to identify the source of the problems. By acting as a preceding "filter", impact evaluation promotes methodologies usually employed in performance audits, widening the range of the work done.

The analyses of the sample reports indicated that there is room to expand audits focused on the effectiveness principle since statistical techniques aiming to identify the impacts of government spending were only verified in reports from three countries. For all of the above, one can reiterate the importance of disseminating good conducting practices for impact evaluation among public Court of Audits in order to perform the examination of government spending from different standpoints.

\section{Conclusions}

This paper analyzed performance audits focused on the effectiveness principle. It started by presenting a concise review of performance audit's historical evolution. Section 2 presented the standards for Performance Audit established by the INTOSAI and also the benchmarks applied by some of the main SAIs in the world. Section 3 introduced the research methods used in the research that grounded this paper and also proceed to present the analysis of the collected data.

The gathering of primary data with auditors from 18 Courts of Auditors shows that practically all of them stated that they undertake audits with an emphasis on the principle of effectiveness; however, it has been observed that most of them limit the analysis to the achievement of predetermined goals, rather than to the impact verified on the target-population resulting from public expenditure.

All things considered, one can conclude that there is a breach in the performance audits undertaken by SAIs in several countries. It is to say that they could be applying impact evaluations to support the commonly used methodologies and, through this, answer population's eagerness for a better control of government spending's results.

As limitations of this study one can verify four aspects: (i) the bibliographic research on performance audit was mainly based on documents written in Portuguese; (ii) when answering the surveys, SAIs auditors stated their personal opinion which not necessarily reflect the Institutions' official position; (iii) since there was not an institutional consultation, several Courts of Audit did not take part on the research; and (iv) the analyzed sample is not extensive enough to positively conclude that the utilization of evaluations of impact of performance audits conducted in global level is low.

Future studies could explore this matter further by: (i) widening the scope of the research through the institutional consult of Court of Counts, and (ii) develop a methodology that aims to simplify the statistical tools needed to undertake performance audits focusing on effectiveness.

\section{References}

Abrucio, F. L. (1997). O impacto do modelo gerencial na administração pública: um breve estudo sobre a experiência internacional recente.Araújo, I. Introdução à auditoria operacional. 4a. Ed., Rio de Janeiro: Ed. FGV, 2008.

Auditing and assurance standards board - ASAE 3500 - Performance Engagements. Retrieved from http://www.auasb.gov.au/admin/file/ content102/c3/ASAE-3500_10-17.pdf

Barros, R. P. D., \& Lima, L. (2012). Avaliação de impacto de programas sociais: por que, para que e quando fazer. Avaliação econômica de projetos sociais, 13-29. 
European court of auditors. Performance Audit Manual. Retrieved from https://www.eca.europa.eu/Lists/ECADocuments/PERF_AUDIT_MANUAL/PERF_AUDIT_MANUAL_EN.PDF

Gertler, P. J., Martinez, S., Premand, P., Rawlings, L. B., \& Vermeersch, C. M. (2016). Impact evaluation in practice. The World Bank.

Hood, C. (1991). A public management for all seasons?. Public administration, 69(1), 3-19.

$\begin{array}{lllllll}\text { ISSAI } & 1 & - & \text { The } & \text { Lima } & \text { Declaration. } & \text { Retrieved }\end{array}$ http://www.intosai.org/issai-executive-summaries/1-founding-principles.html

ISSAI 300, Fundamental Principles of Performance Auditing. Retrieved from http://www.intosai.org/issai-executive-summaries/3-fundamental-auditing-principles.html.

ISSAI 3000, Standards and guidelines for performance auditing based on INTOSAI's Auditing Standards and practical experience. Retrieved from http://www.intosai.org/issai-executive-summaries/4-auditing-guidelines/general-auditing-guidelines.html.

Morse, E. (1976). Performance Auditing - What is it? Presented in the $9^{\circ}$ Annual Governmental Seminar in Jefferson City, Missouri, in April 21.

Mury, L. (2018). Auditorias Operacionais com foco no princípio da efetividade: breve panorama junto aos tribunais de contas do Brasil. Revista de Auditoria Governança e Contabilidade, 6(25). For coming.

National Audit Office of Finland. Performance Audit Manual (translation), Helsinki: Ed. Prima Ltd, 2007.

Pollitt, C., Girre, X., Lonsdale, J., Mul, R., Summa, H., \& Wearness, M. (2009, January). Esempenho ou legalidade? Auditoria operacional e de gestão pública em cinco países. Editora Forum.

Sano, H. (2003). Nova Gestão Pública e accountability: o caso das organizações sociais paulistas (Doctoral dissertation).

Santos, A. (2006). Metodologia Científica: a construção do conhecimento. Rio de Janeiro: Ed. DP\&A.

Tribunal de Contas da União - TCU. Manual de auditoria de natureza operacional. $1^{\text {st }}$. Brasília: TCU, Coordenadoria de Fiscalização e Controle, 2000.

Tribunal de Contas da União - TCU. Manual de auditoria operacional. 3ª Ed. Brasília: TCU, Secretaria de Fiscalização e Avaliação de Programas de Governo (Seprog), 2010.

United States General Accounting Office - GAO. Government Auditing Standards 2011 Revision. Retrieved from https://www.gao.gov/yellowbook/overview.

United States General Accounting Office - GAO. Standards for Audit of Governmental Organizations, Programs, Activities \& Functions. Retrieved from http://www.gao.gov/assets/680/676159.pdf.

Vabo, M. (2009). New public management: The neoliberal way of governance. Félagsvísindastofnun Háskóla Íslands: http://ts. hi. is/Working\% 20Paper, 204-2009.

\section{Notes}

Note 1. The author had access to the Brazilian edition of the book. Therefore all citations were translated from Portuguese to English which may cause differences from the original but with no loss regarding meaning.

Note 2. The International Organization of Supreme Audit Institutions is a non-political organization affiliated to the UN. Its objective is to exchange ideas and transfer knowledge on the best practices of public audit in the world. Retrieved from www.intosai.org.

Note 3. Criterion is a standard or principle on which a judgment is based. The standard implies some form of measurement - cardinal, ordinal or nominal - that can be used as the basis for comparison purposes of comparing (Pollit et al., 2008, p. 130).

Note 4. Besides thee three 'E's, a fourth ' $E$ ' is applied in some places:

IV. Equity: The extent to which services are available to and reach all people that they are intended to - spending fairly. Some people may receive differing levels of service for reasons other than differences in their levels of need.

Note 5. The principle of environment means considering if government programs are managed with due regard to the effects on the environment while conducting an audit.

Note 6. One example is the opposition against the comparison between executive agencies and foreigner organizations in the UK. Pollit et al., 2008, p. 298. 
Note 7. Reports from countries where English is not the official language presented at least an executive content table in English.

Note 8. Specific, Measurable, Attainable, Relevant, Time-Specific.

\section{Copyrights}

Copyright for this article is retained by the author(s), with first publication rights granted to the journal.

This is an open-access article distributed under the terms and conditions of the Creative Commons Attribution license which permits unrestricted use, distribution, and reproduction in any medium, provided the original work is properly cited. 